\title{
Interpretation of salt-cored frontal structures in the Southern Pyrenees guided by analog modeling, surface and subsurface data
}

\author{
Eloi Carola ${ }^{1}$, Oriol Ferrer ${ }^{2}$, Oskar Vidal-Royo ${ }^{2}$, and Josep Anton Muñoz ${ }^{2}$
}

\begin{abstract}
Southern Pyrenean frontal thrusts are usually blind or partially covered by syn- and posttectonic sediments of the Ebro Foreland hampering their interpretation. We have investigated the geometry and evolution of the Súria Anticline, a frontal structure of the Southern Pyrenees, which is characterized by the presence of multiple buried and blind thrusts displaying a complex triangle zone and several fishtail structures at depth. To characterize the geometry and structural evolution, a combination of surface geology, subsurface data interpretation, and analog modeling have been integrated into a unique 3D geologic model. The surface geology of this area depicts a rather simple structure, characterized by a north-directed backthrust and a gentle anticline, both striking west-southwest/east-northeast. In contrast, geophysical data indicate that the subsurface structure is more complex, exhibiting several northward- and southward-directed thrusts and folds detaching on the Pyrenean foreland Eocene evaporites. Integration of surface (geologic maps and dip measurements) and subsurface data (seismic and wells) allowed us to reconstruct the 3D structure of this area. To produce a more robust kinematic model, we used an experimental approach to investigate the evolution of frontal structures in folds and thrust belts on evaporitic detachments. Different viscous layer configurations were tested in a series of sandbox models comparing them with the evolution of the Súria Anticline. Taking into account the deformation and that seismic quality is in general poor, the experimental model results allow us to better characterize the structures developed in this area. Our structural evolution is characterized by an early stage of salt inflation and fold nucleation. With increasing shortening, the structure evolved to a detachment anticline eventually developing a northward-directed thrust that broke through the northern anticline limb. The present-day geometry developed in a later stage of fold reactivation, when a new regional fold formed, and tightened the preexisting structure.
\end{abstract}

\section{Introduction}

Structures in the external domains of fold and thrust belts are characterized to be partially covered or blind by syn- or post-tectonic sediments thus making it more difficult to understand the evolution and the geometry of the riding nappe over the foreland. This fact can be partially solved using seismic reflection surveys. Seismic data are generally acquired and processed in such a way that the exploration targets are better displayed penalizing the shallower or the deeper parts of the section. When the shallower levels are poorly illuminated, the integration of surface data and field mapping allows workers to constrain the fold geometry and to better understand its evolution (Zapata and Allmendinger, 1996; Mencos et al., 2015: among others). In areas with good outcrop and stratigraphic control, it is even possible to precisely reconstruct the evolution of these structures using paleomagnetism, fission track, and other field-based studies (Muñoz et al., 2013; Fillon et al., 2016). The use of analog modeling has shown its potential to better characterize and constrain the evolution of structures thus reducing the uncertainty and discarding nonreproducible alternatives (Bahroudi and Koyi, 2003; Jackson and Hudec, 2005; Dooley et al., 2009).

Our study focuses on the geometry and development of a frontal structure located at the Southern Pyrenees. The stratigraphy of the area is characterized by the presence of several evaporitic levels acting as detachment layers that controlled the structural development of the external domains of the Pyrenean Orogen. On one hand, surface geology suggests that the Súria Anticline seems to be a rather simple anticline with a backthrust at its southern limb. On the other hand, geophysical data indicate that the deeper section is characterized by several north- and south-directed thrusts. The

\footnotetext{
${ }^{1}$ Gas Natural Fenosa, Madrid, Spain and Universitat de Barcelona, GEOMODELS Research Institute, Departament de Dinàmica de la Terra i de l'Oceà, Barcelona, Spain. E-mail: eloicarola@gmail.com.

${ }^{2}$ Universitat de Barcelona, GEOMODELS Research Institute, Departament de Dinàmica de la Terra i de l'Oceà, Barcelona, Spain. E-mail: joferrerr@ub.edu; vidal.oskar@gmail.com; jamunoz@ub.edu.

Manuscript received by the Editor 23 June 2016; revised manuscript received 11 November 2016. This paper appears in Interpretation, Vol. 5, No. 1 (February 2017); p. 1-16, 10 FIGS., 1 TABLE.

http://dx.doi.org/10.1190/INT-2016-0093.1. @ 2017 Society of Exploration Geophysicists and American Association of Petroleum Geologists. All rights reserved.
} 
fact that deeper levels do not outcrop and the seismic image of the shallow level is of poor to moderate quality hinders the interpretation of the area.

The integration of surface geology and subsurface data allowed us to reconstruct the 3D structural geometry of the Súria Anticline. Analog models were used to constrain our structural evolution for this salt-cored structure.

\section{Geologic setting Regional description of the Pyrenees}

The Pyrenees are the east-west elongated doubly vergent orogen dividing the Iberian and Eurasian plates (Figure 1a). This orogen resulted from the convergence and subduction of the Iberian plate underneath the Eurasian plate during the Late Cretaceous-Cenozoic (Le Pichon and Sibuet, 1971; Muñoz, 1992, 2002; Beaumont et al., 2000). The Pyrenean orogen is subdivided along strike into different portions that are characterized either by thick- or thin-skinned tectonics (MartínezTorres, 1993; Pulgar et al., 1996; Gallastegui, 2000; Muñoz, 2002; Pedreira et al., 2003; Ferrer et al., 2008; Martín-Gonzalez and Heredia, 2011; Carola et al., 2015).

The Pyrenees sensu strictu, the central portion, are characterized by a south-verging antiformal stack of basement and cover units (Figure 1a). The external domains of the orogen are characterized by thin-skinned tectonics in which thrusts progressively climb up toward the Ebro and Aquitanian foreland basins (Muñoz, 1992, 2002; Vergés et al., 1992; Biteau et al., 2006). The central areas of the Ebro Foreland Basin are characterized by the presence of two main evaporitic units, Lutetian and Priabonian in age, which are the main detachment units along which deformation propagated southward. These two units are spatially disconnected, the Cardona salt unit is located southward and shallower than the Beuda salt unit. The presence of two detachment levels at different stratigraphic and palegeographic positions allows the deformation front of the Pyrenees to climb up over the Ebro Foreland Basin. The study area is located in the southernmost structures of the Pyrenean orogen (Figure 1b) in which the evaporitic units of the Ebro Foreland Basin influenced the development of the fold and thrust belt (Figure 1c).

\section{Stratigraphy of the study area}

The main characteristic of the sedimentation of the Ebro Foreland Basin is that the environment switched from marine to continental through time (Puigdefabregas et al., 1986) (Figure 1d). The lowermost unit, described in this study, is the Igualada Formation (Paleocene-Eocene) made up of gray deltaic marls. During this marine to continental transition, two evaporitic units (the Beuda Formation and the Cardona Formation), which will be the focus of the analog modeling presented in this study, were deposited in a marine-restricted environment. The Beuda Formation (Lutetian) is less studied because of its restricted outcropping con- ditions. Well data show that this unit is at least approximately $1000 \mathrm{~m}$ thick, made up of alternating shales and anhydrites and with $100 \mathrm{~m}$ of salt above it (Martínez et al., 1989). In contrast, the Cardona Formation (Priabonian) has been well-described in field studies in the eastern part of the foreland, as well as at depth thanks to the presence of several hydrocarbon and mining exploration wells and industrial activity (Reguant, 1967; Pueyo, 1975; Rosell and Pueyo, 1997; Busquets et al., 1985; Vergés and Muñoz, 1990). The Cardona Formation is characterized by a lower member constituted by 5 $10 \mathrm{~m}$ thick anhydrite followed by alternations of gray and white halite with gray to brown marls. Above this layer, there is a member of approximately $40 \mathrm{~m}$ of alternations of carnalite and silvinite. Finally, the upper member is composed of gray marls interbedded with pink and gray halite. The thickness of this unit is difficult to assess due to intense folding in the evaporitic layers. At the basin margin, this unit is only made up of anhydrites. The continental succession is characterized by evaporites at the base that progressively evolve to carbonatic and siliciclastic sediments. The Barbastro Formation (Eocene-Oligocene) (Figure 1d) located at the base of the succession is composed of gypsum reaching a thickness of approximately $200 \mathrm{~m}$ in the study area, although more than $1000 \mathrm{~m}$ of salt has been drilled in the basin center (Sáez, 1987). The Castelltallat Formation (Oligocene) (Figure 1d) is a $50 \mathrm{~m}$ thick lacustrine limestone with evaporitic influence. Finally, the siliciclastic Artés and Solsona Formations are a succession of alternating sandstones (locally microconglomerates) with red clays. In restricted areas, limestones and gray marls are also characteristic of these formations. The source area of the Artés Formation is attributed to the Catalan Coastal Ranges, whereas the source area of the Solsona Formation is believed to be the Pyrenees according to Ferrer (1971) and Sáez (1987) (Figure 1a and $1 b)$.

\section{Main structures of the South Pyrenean Triangle Zone}

The southern wedge of the Pyrenean thrust and fold belt is characterized by thin-skinned tectonics (Figure 1c). Cover thrust sheets are detached on evaporitic layers (i.e., Upper Triassic Keuper facies, Beuda Formation, Cardona Formation, and evaporitic horizons of the Barbastro Formation) and are transported southward over the Ebro Foreland Basin (Muñoz, 1992; 2002; Vergés et al., 1992; Sans and Vergés, 1995; Sans et al., 1996). In the southernmost deformed area (South Pyrenean Triangle Zone), the main folds and faults strike northwest-southeast (e.g., Sanaüja, Puig-Reig anticlines, and the deformation front among others) and southwest-northeast to west-southwest/east-northeast such as the Cardona Anticline, El Guix Anticline, and the Suria Anticline (Figure 1b). The study area is located at the eastern tip of the Súria Anticline (Figures 2 and 3a). The area is characterized by a westsouthwest/east-northeast gentle fold (Súria Anticline), 
associated with a subparallel contractional fault (the Tordell Thrust) located at the southern limb of the fold. Collected field data display a shallowly dipping struc- ture in surface, with values of $20^{\circ}$ or less. The stereographic projection displays two clusters of data associated with the two limbs of the fold with a fold axis

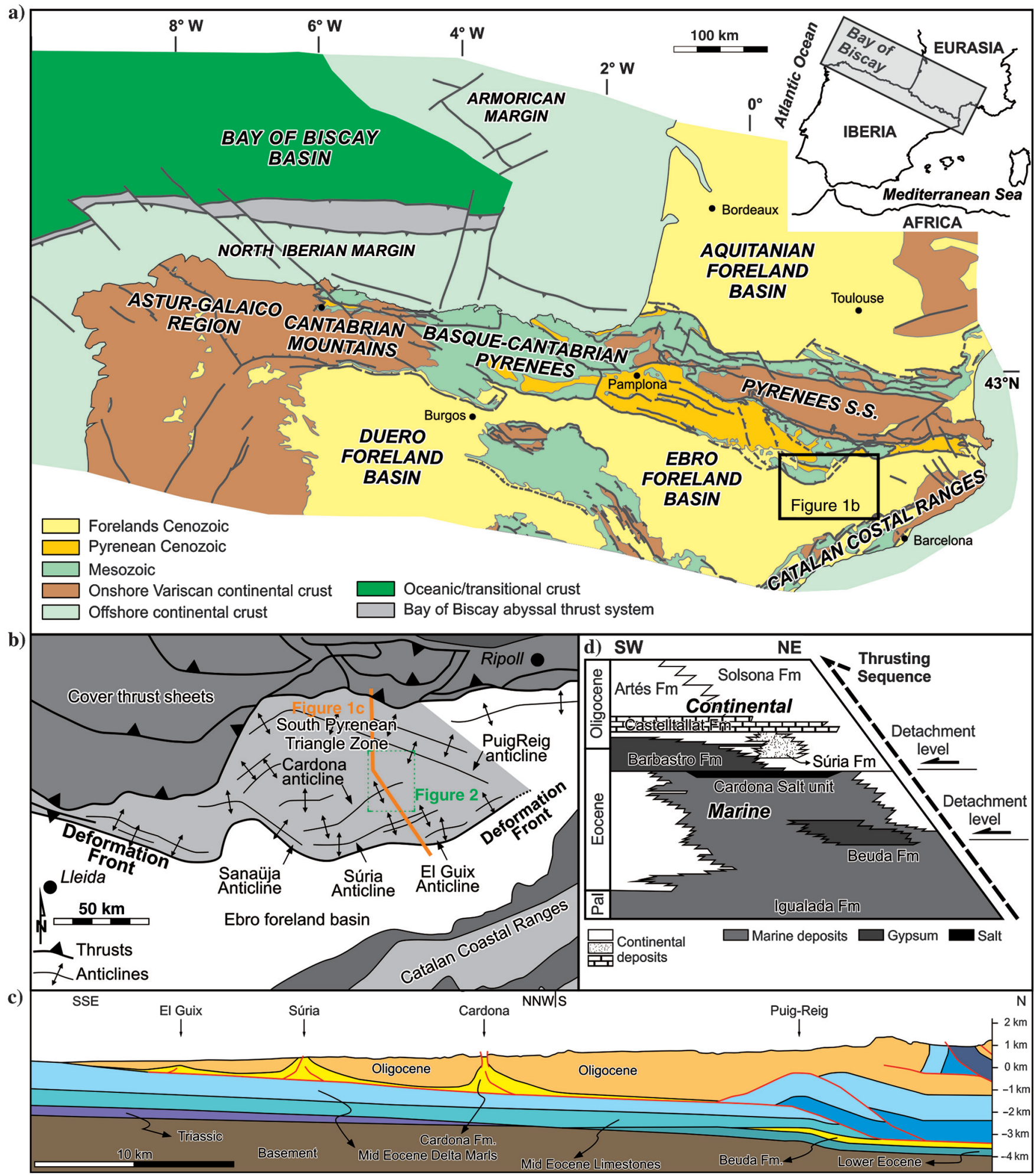

Figure 1. (a) General map of the Pyrenees with associated foreland basins (modified from Muñoz, 2002). (b) Detailed map of the Serres Marginals thrust sheet and Southern Pyrenean Triangle Zone (redraft from Sans et al., 2003). (c) South-southeast/northnorthwest simplified cross section of the external parts of the Pyrenees (modified from Vergés et al., 2002) (see the location in panel b). (d) Stratigraphic chart showing the main formations as well as the main detachment levels of the study area (redraft from Sans et al., 2003). 
oriented 01/251 (Figure 3b). The Tordell Thrust outcrops westward of the study area at the Tordell creek where it was defined by Ramírez del Pozo et al. (1973) (Figure 2). The fault is here characterized by two slipping surfaces that are rooted at the deepest section of the outcrop (covered by trees in Figure 4a). The strata located in their footwall, away from the fault plain, has low dip angles (less than $17^{\circ}$ ) and lacks severe deformation (Figure $4 \mathrm{~b}$ ). Close to the fault, the main structure is a footwall syncline with an overturned limb (Figure 4c). The hanging wall is characterized by a series of gentle anticlines. The displacement of the reverse fault, determined by regional fieldwork, is in the range of tens of meters. Eastward, the trace of the Tordell Thrust becomes discontinuous, and the displacement of the fault decreases. In this area, deformation is characterized by the development of fishtail structures with north- and south-directed thrusts and a reduced amount of displacement of less than $10 \mathrm{~m}$ (Figure 4d). At the easternmost outcrop of the Tordell Thrust (Figures 3 and 4e), the displacement is almost null and deformation is mostly accommodated in the footwall by tilted sandstone bodies and sheared clays (Figure 4f). The slickenlines present on the fault plain are dip slip, and the sense of movement indicates that the hanging wall was displaced northward (Figure 4g). These observations are in agreement with the deeper

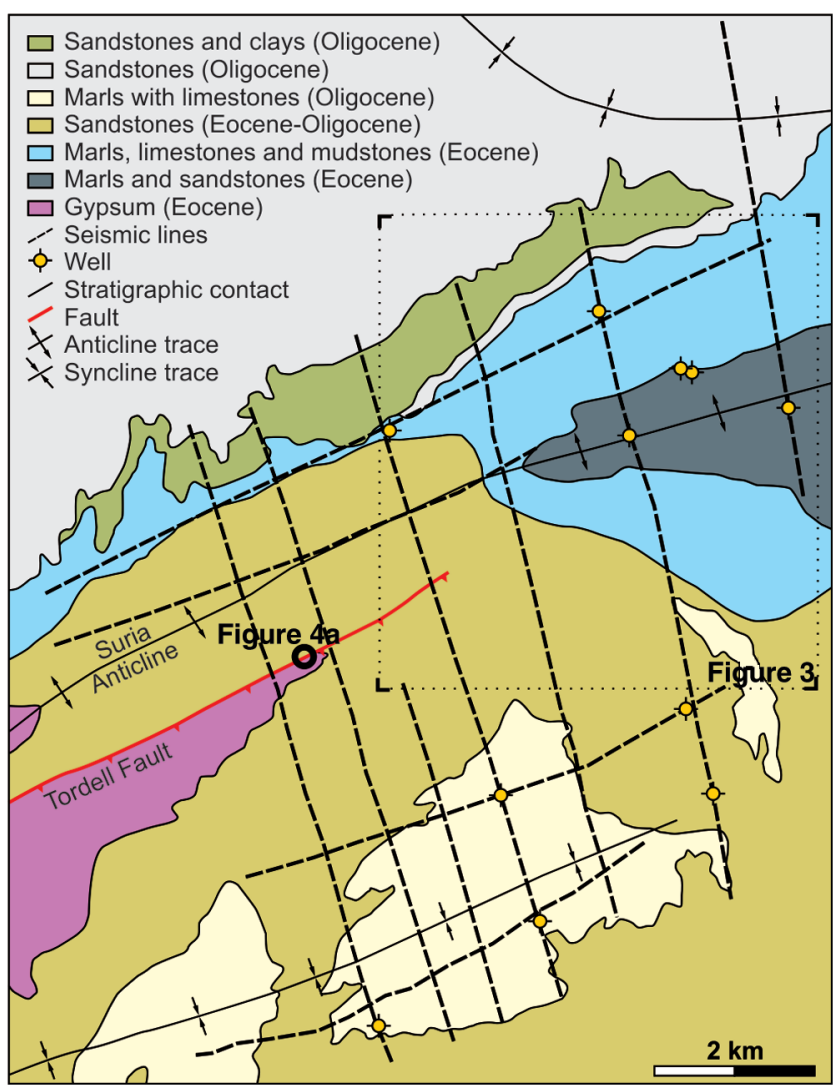

Figure 2. Schematic geologic map, redraft from ICC (2006) with the location of the different seismic lines and wells used to constrain the deeper geometry of the area. geometries described by Sans et al. (1996) through seismic and well data interpretations.

\section{Methodology and data sets}

The methods and the data sets used in this study can be referred to two different procedures: 3D structural modeling and analog (sandbox) modeling.

\section{D structural modeling: The eastern tip of the Tordell Thrust}

The integration of surface and subsurface data interpretations allowed us to reconstruct the $3 \mathrm{D}$ structural geometry and to understand the structural relationships at the eastern tip of the Tordell Thrust. The seismic data set, acquired during the late $1990 \mathrm{~s}$, is constituted by a total of 12 seismic lines, eight north-south and four west-east, covering the study area (Figure 2). Well data were derived from 11 exploration wells drilled from the late 1980 s to 2011 , some of them in the intersection of the seismic lines (Figure 2). Five wells crossed the whole evaporitic succession of the Cardona Formation reaching the unit immediately below (the Igualada Formation). Six wells drilled up to different evaporitic units of the Cardona Formation without reaching its base. Fieldwork constituted of geologic mapping on 1:25,000 ortophotographs coupled with field mapping and outcrop data observations (Figure 3). In this study, more than 800 new dip data were gathered (Figure 3). In addition, more than 90 stratigraphic bedding traces were digitized to extract more dip data.

\section{Analog modeling: Distribution of viscous detachment levels in fold belts}

A series of analog models were carried out aiming to reproduce 2D frontal structures in fold and thrust belts. Particularly, the models investigated how the presence, absence, and distribution of viscous detachments affect the development and evolution of such structures. Models were carried out in the GEOMODELS Analogue Modelling Laboratory at the University of Barcelona. The modeling rig was constituted by two fixed-glass walls and two motor-driven mobile end walls mounted in a tiltable baseboard (Figure 5). Time-lapse photographs of the model were taken from the two lateral glass walls and from the top every 2 min to track the evolution. Well-sorted dry sand of $199 \mu \mathrm{m}$ was used to simulate the brittle behavior of rocks in nature (Table 1). The mechanical properties of the poured sand were determined by a shear box test resulting in an internal friction of $34.6^{\circ}$, a bulk density of $1500 \mathrm{~kg} \mathrm{~m}^{-3}$, a coefficient of internal friction of 0.69 , and a low apparent cohesive strength of $55 \mathrm{~Pa}$. Our salt analog was a silicone polymer (Rhodia Rhordosil GUM FB) with an almost-Newtonian behavior (Table 1) (Dell'Ertole and Schellart, 2013). These materials are widely used in analog modeling studies and especially in salt tectonics due to its comparable behavior to salt (Weijermars et al., 1993). The scaling ratios between the experiments and nature, using a deviatoric stress value taken from 
Schellart (2000), are presented in Table 1. The experimental program presented in this work was carried out in a $77 \mathrm{~cm}$ long and $30 \mathrm{~cm}$ wide glass-sided deformation rig (Figure 5). Models were constructed between two end walls: one fixed and the other moved by a servomotor-driven worm screw controlled by computer at a constant displacement rate of $30 \mathrm{~mm} / \mathrm{h}$ (Figure 5). The total thickness of the models before deformation was $25 \mathrm{~mm}$ (Figure 6), and a total shortening of $184 \mathrm{~mm}$ was applied to each model. The total shortening and the displacement rate, taking into account the natureto-analog ratio, give a simulated geologic time corresponding to 14 million years. Four different initial configurations were considered in our physical models. A model constituted only by silica sand and without a basal detachment was carried out to use it as a baseline (Figure 6a). The model with a simple detachment was performed using a $5 \mathrm{~mm}$ thick layer of viscous polymer covering the whole base plate (Figure 6b). The configuration of the model with a frontal backstop included a rigid wooden block with an angle of $20^{\circ}$ and a $5 \mathrm{~mm}$ thick basal detachment made with polymer (Figure 6c). Finally, the model with two detachment layers incorporates two $30 \mathrm{~cm}$ long, $15 \mathrm{~cm}$ wide, and $0.5 \mathrm{~cm}$ thick polymer patches simulating the two evaporitic detachments of the external parts of the Pyrenean Chain (Beuda and Cardona Formations) (Figure 6d). As shown in Figure 6d, these two layers were located at different depths and were horizontally offset such that there was no overlap. The lower one, located at $17 \mathrm{~cm}$ from the moving end wall, was made by transparent polymer and included a passive marker of blue polymer with the same mechanical properties of pure polymer (Figure 6d). In contrast, the upper one, bright green in color, was located $6 \mathrm{~mm}$ higher than the lower one and at $32 \mathrm{~cm}$ from the moving end wall. To mini-

a)

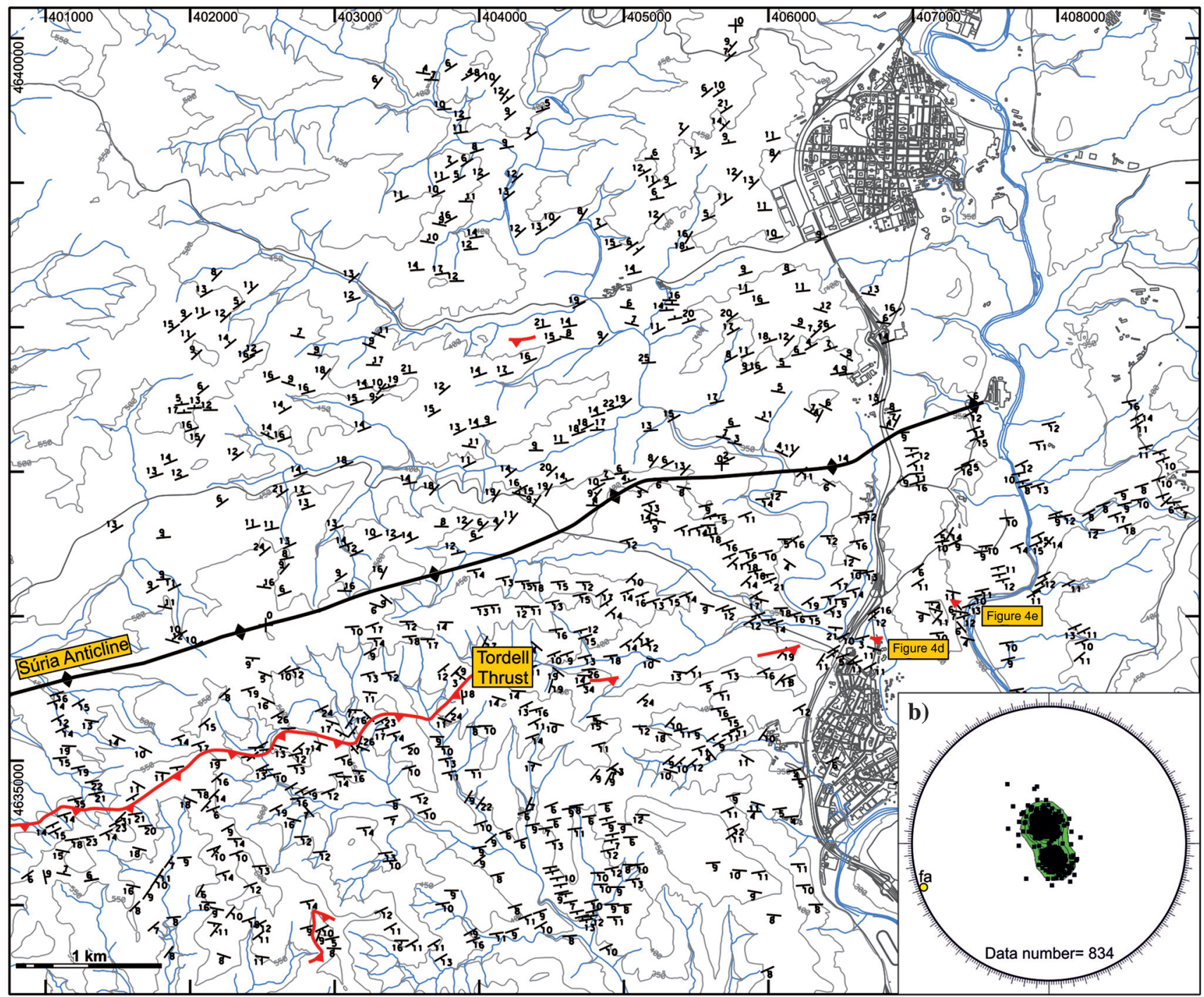

Figure 3. (a) Detailed structural map of the study area with indicated the location of the outcrops illustrated in Figure 4 (b) Dip data bedding poles stereoplot with fold axis (fa) of the study area. Stereographic projections in a lower hemisphere equal-area plot are generated with OpenPlot software (Tavani et al., 2011). 
mize lateral structures and to control lateral effects of the sidewalls, both silicone layers covered the total width of the model. In front of the acid green silicone,
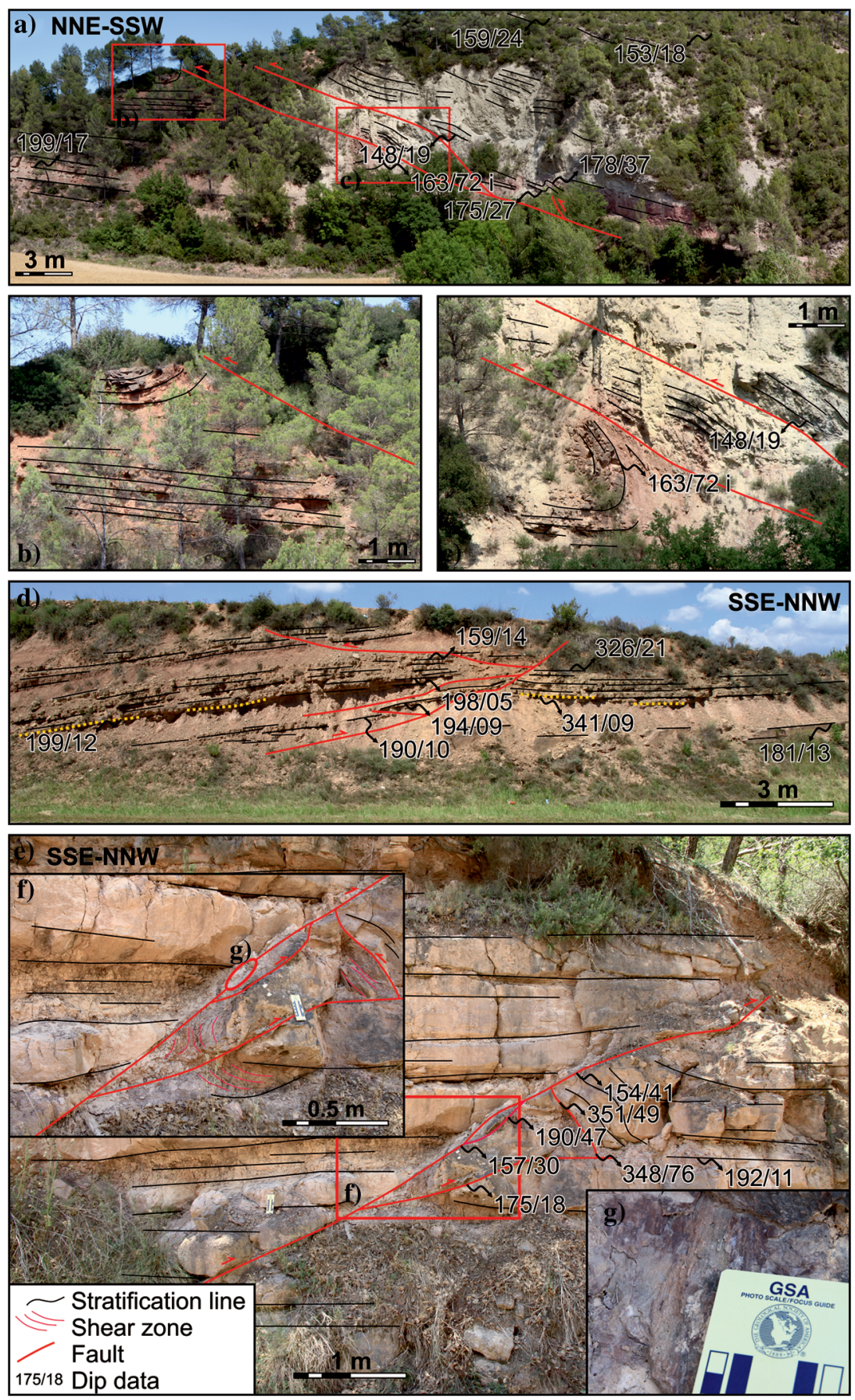

Figure 4. Outcrop examples along the Tordell Thrust showing the variation of displacement along-strike and bedding attitudes $\left(S_{0}\right)$. (a) Main outcrop at the Tordell creek (westward of the study area) where two small faults rooted at the deepest part of the Tordell Thrust (see Figure 2 for location). (b) Detail of footwall deformation in the lowermost thrust. (c) Detail of footwall syncline produced by the displacement of the hanging wall. (d) Small-scale fishtail deformation in the Tordell fault showing less-than-metric-scale displacement. (e) Easternmost outcrop of the Tordell fault with almost-zero displacement. (f) Detail of the fault core. (g) Dip-slip slickenlines on the fault plane shown in panel (f), notice the $1 \mathrm{~cm}$ rectangle of the scale bar. a total length of $30 \mathrm{~cm}$ of dry sand was put to simulate the fluvial sequences of the Ebro Foreland Basin and to minimize border effects with the fixed end wall. This distribution is justified by the fact that in the Southern Pyrenees, the southward migration of the foredeep through time conditioned the location of the evaporitic layers in the foreland. The result of this evolution is that the Beuda (represented by transparent polymer) and Cardona (represented by bright green polymer) evaporitic formations were horizontally and vertically offsets, respectively (Vergés et al., 1992, 2002).

\section{Results}

\section{D structural modeling}

The 3D structural model of the area, constrained by the use of seismic, well, and surface data, is characterized by the presence of a major north-directed backthrust and other minor north- and south-directed thrusts that deform the whole area (Figure 7a). The main detachment level in this area is the Priabonian evaporitic sequence belonging to the Cardona Formation (Vergés et al., 1992; Sans and Vergés, 1995; Sans et al., 1996; Muñoz, 2002). The formations below the evaporitic salt unit (Igualada Fm) remain undeformed and only display the foreland flexure, dipping $4^{\circ}$ northward, produced by the advance of the fold and thrust belt (Figure $7 \mathrm{~b}$ ). In contrast, the different formations of the thrust sheet are severely affected by faults and the whole cover is deformed. In the area, two main westsouthwest/east-northeast anticlines almost parallel to the trace of the main faults are interpreted (Figure 7c-7e). The southernmost anticline is located to the south of the trace of the Tordell Thrust. Structural relief decreases eastward along the fault and the anticline (Figure 7c-7e). In contrast, the Súria Anticline spans the whole study area exhibiting no decrease in structural relief (Figures 3 and $7 \mathrm{c}-7 \mathrm{e}$ ). The traces of the anticlines interpreted, from the seismic lines, for each unit are located almost at the same position in map view with a few meters of difference (Figure 7f). The most important observation at this point is the absence of the southernmost anticline at the surface, where only a south-dipping monocline is present (Figures 3, 7f, and 8a). In contrast, the deeper anticline traces of 
each unit perfectly match with the surface geology trace of the Súria Anticline (Figures 3, 7f, and 8a). This confirms that the deformation between the deeper and shallower layers was decoupled at the time of structural growth in the area. In contrast, the deformation occurred in a single phase during the development of the Suria Anticline as revealed by the analysis of the anticline traces (Figure 7f). This is a key point to understand the evolution of the area and to reconstruct the geometry of the prefolding stage. The almost-parallel trace of the southern fold with the trace of the Tordell Thrust plus the decrease in the structural relief and fault displacement to the east and the decoupling between surface and subsurface data allows us to interpret the southern anticline to be related with the development of the Tordell fault in the early stages of deformation. In a second stage of deformation, the

Table 1. Scaling parameters used in the experimental program.

\begin{tabular}{|c|c|c|c|}
\hline & Experiment & Nature & Model ratio \\
\hline \multicolumn{4}{|l|}{ Thickness } \\
\hline Total thickness & $2.5 \mathrm{~cm}$ & $2.5 \mathrm{~km}$ & $1 \times 10^{-5}$ \\
\hline Mobile unit & $0.5 \mathrm{~cm}$ & $0.5 \mathrm{~km}$ & $1 \times 10^{-5}$ \\
\hline \multicolumn{4}{|l|}{ Density } \\
\hline Overburden & $1500 \mathrm{~kg} / \mathrm{m}^{3}$ & $2300 \mathrm{~kg} / \mathrm{m}^{3}$ & 0.72 \\
\hline Mobile unit & $972 \mathrm{~kg} / \mathrm{m}^{3}$ & $2100 \mathrm{~kg} / \mathrm{m}^{3}$ & 0.46 \\
\hline $\begin{array}{l}\text { Mobile unit } \\
\text { viscosity }\end{array}$ & $1.6 \times 10^{4} \mathrm{Pas}$ & $\begin{array}{c}10^{18} \text { to } \\
10^{19} \mathrm{~Pa} \mathrm{~s}\end{array}$ & $\begin{array}{l}1.6 \times 10^{-14} \text { to } \\
1.6 \times 10^{-15}\end{array}$ \\
\hline $\begin{array}{l}\text { Overburden } \\
\text { coefficient friction }\end{array}$ & 0.7 & 0.8 & 0.87 \\
\hline $\begin{array}{l}\text { Gravity } \\
\text { acceleration }\end{array}$ & $9.81 \mathrm{~m} / \mathrm{s}$ & $9.81 \mathrm{~m} / \mathrm{s}$ & 1 \\
\hline Time & $1 \mathrm{~h}$ & 237000 year & $4.8 \times 10^{-10}$ \\
\hline Velocity & $30 \mathrm{~mm} / \mathrm{h}$ & $12.2 \mathrm{~mm} /$ year & $2.0 \times 10^{4}$ \\
\hline
\end{tabular}

Súria Anticline grew by folding across the entire area. Knowing the structural evolution allows us to restore the geometry of the structures back to a prefolding stage. This, in turn, provides us with a better understanding of the geometry and structural framework that triggered the development of the Tordell Thrust and associated anticline. To do that, three horizons have been created in the 3D geologic model from surface dip data (green, yellow, and orange lines in the cross section of Figure 8a). These layers are then restored to the horizontal to know the prefolding geometry of the deeper levels. The prefolding stage of the area is characterized to the north by a rather undeformed area without much structural relief and to the south by the presence of the Tordell Thrust and associated anticline (Figure 8b). Restoring the Súria Anticline using the bed-length method resulted in $2 \%$ of bulk shortening, without taking into account the effects of layer-parallel shortening. Once the $2 \mathrm{D}$ section was partially restored, a $3 \mathrm{D}$ restoration of the postfolding units was performed (Figure 8c). The resultant geometry shows how the displacement and structural relief along the Tordell Thrust decrease eastward. The basal unit modeled in the area (Igualada Formation) was not restored because the overburden is detached and displaced southward, thus making it impossible to know the exact thickness of the salt unit. In addition, the lack of good seismic resolution at deeper stratigraphic levels makes it difficult to infer a possible lateral salt flow during the initial stages of contraction when salt inflation took place.

\section{Analog modeling}

The experimental results show how, in models in which an effective detachment layer is present, the deformation can be transferred far into the foreland as opposed to models lacking effective detachment levels (Figure 6a-6d). Models with a constant basal detachment are characterized by the development of regularly spaced structures, and almost all structures developed

a) Initial setup

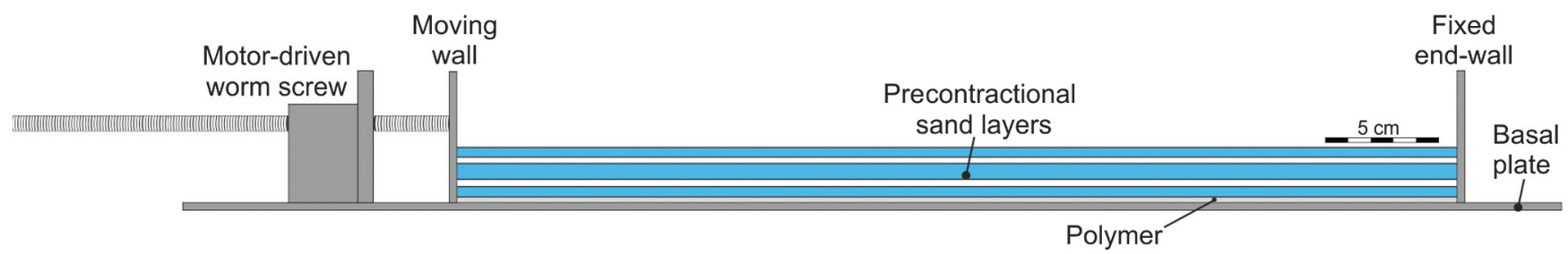

b) End of contraction

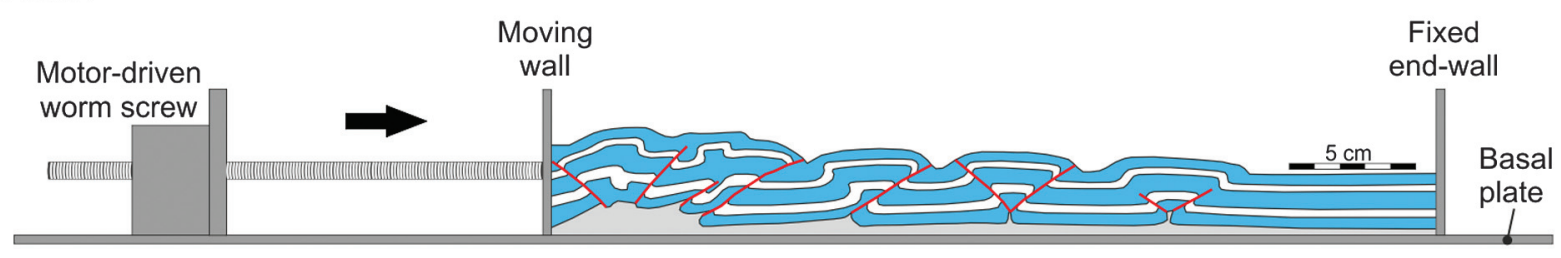

Figure 5. Analog modeling laboratory configuration (a) before deformation and (b) after deformation representing the key elements of the modeling rig. 
grew as symmetrical detachment folds that evolved developing thrusts and attaining a foreland vergence (Figure $6 \mathrm{~b}$ and $6 \mathrm{c}$ ). The models without or with only one ductile detachment are not described in detail, due to the fact that the key elements described in the study area, shown in Figure 1c, cannot be reproduced by these vertically and horizontally offset configurations. In contrast, the development of frontal structures in the set of models with two detachment layers reproduces similar geometries to the ones described in the study area (Figure 6d). This model setup typically follows a constant evolution characterized by salt inflation, growth of a detachment anticline, generation of a thrust fault, and reactivation of some of the structures of the hinterland. This is repeated for the different structures with a normal propagation of thrusts toward the foreland. In detail, the first step of deformation is reflected in an undeformed area by a slight inflation of the ductile layer at the tip of the deformation front (the green arrow in Figure 9 and the deformation front line in Figure 10). Following the contraction, the salt-inflated area turns into the development of a detached an-

\section{a) Nonsilicone detachment}
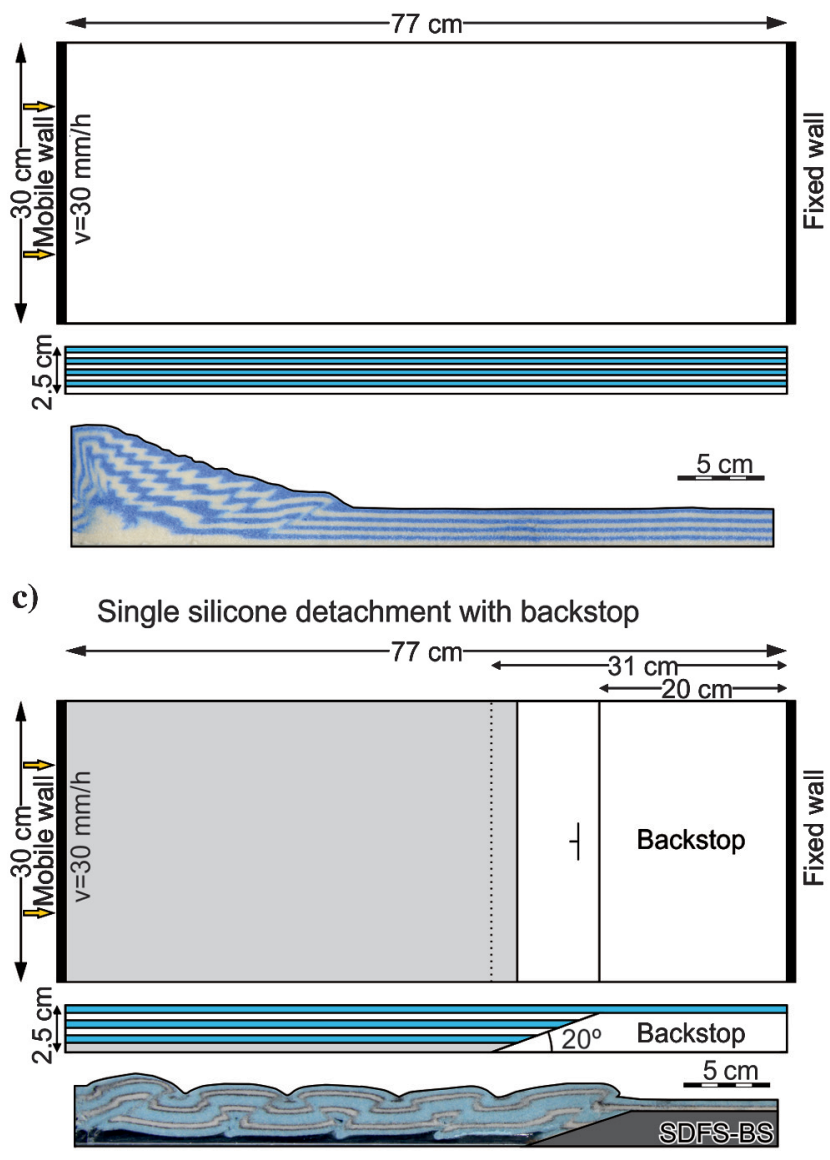

ticline (the blue arrow in Figure 9 and the incipient anticlines in Figure 10). As deformation continues, the anticline grows up to a point in which a backthrust starts to form at the frontal limb developing some structural relief (the red arrow in Figure 9 and the thrusts of Figure 10). The sequence of deformation is repeated as the deformation advances toward the foreland. The use of serial time maps is a powerful tool to track the evolution of structures and their timing. The map views shown in Figure 10 allow identification of the cyclical pattern of the frontal structure development described before. As shown in this figure, some frontal structures started to develop by the linking of small faults, whereas in other domains, a structure with reduced length formed, later broadening and bending until a spoon-shaped geometry was reached. With increasing shortening, structures acquire more structural relief and also new structures are developed toward the foreland. The amount of horizontal displacement of the deformation front between stages $\mathrm{A}$ and $\mathrm{C}$ is $7.5 \mathrm{~cm}$, as opposed to the $3.3 \mathrm{~cm}$ of stages D to F (Figure 10). This decrease of displacement at later stages is due to the b)

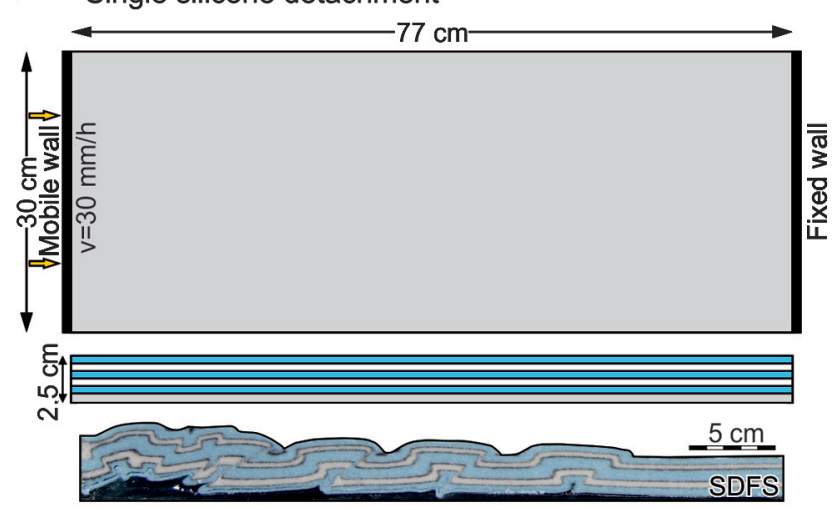

d)

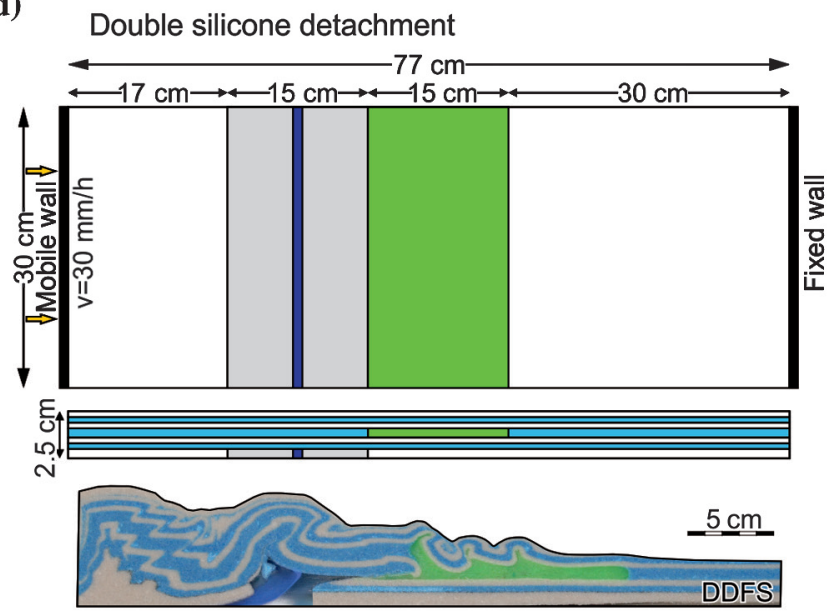

Figure 6. Model setups performed to study the development of frontal structures with different nature, geometry, and stratigraphic location of the detachment level. (a) Model made up of quartz sand. (b) Model with a basal layer of silicone covering the whole area. (c) Model with a basal layer of silicone and a frontal backstop. (d) Model with two layers of silicone located at different positions. Sections shown are located in the middle of the model. 
deformation being easily transferred toward the foreland when an effective and long detachment layer is present, decreasing when the deformation front reaches the salt pinch-out. In addition, the use of serial maps allowed us to identify reactivation and overprinting of some structures during the evolution of the model, as shown in Figure 10. Between stages A and D, a hinterlanddirected thrust, generated by the linkage of two small faults, is overprinted by a foreland-directed thrust thus making it difficult to interpret if only the final time step was used.

\section{Evolution of the Súria Anticline and the Tordell Thrust}

Taking into account all the data and observations, the evolution proposed for the Súria Anticline and the Tordell Thrust is rather similar to the one displayed by the analog models. The initial stages of deformation were characterized by salt inflation. As deformation progressed, the salt-inflated area turned into a detached anticline. With increasing shortening, the Tordell Thrust developed, increasing the structural relief and displacing the previously developed anticline northward along its hanging wall. The deformation was then transferred toward the south, and a period of tectonic quiescence took place thus covering the Tordell Thrust and associated anticline. Transfer of the deformation resulted in the formation of a new structure toward the foreland (the El Guix Antlicline). Finally, reactivation occurred at a later stage and the Súria Anticline was formed, thus deforming the entire area.

\section{Discussion}

The experimental results showed that thrusts are almost constantly spaced between them during the initial stages of shortening (Figures 9 and 10). In contrast, the spacing decreases toward the end of the modeling as the deformation front approaches the salt pinchout. This fact is a well-known feature in analog models: Among other factors, the thrust spacing depends on the presence/absence of an efficient detachment layer and its distribution, the regional angle, and the presence/absence of pore fluids (Letouzey et al., 1995; Bonini, 2001, 2003; Agarwal and a)

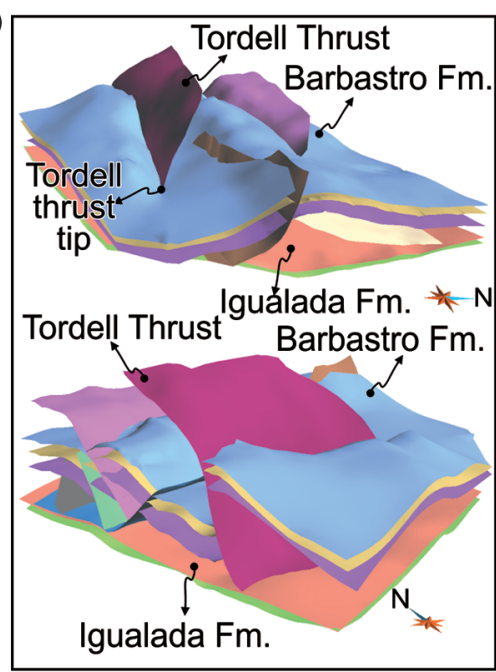

b)

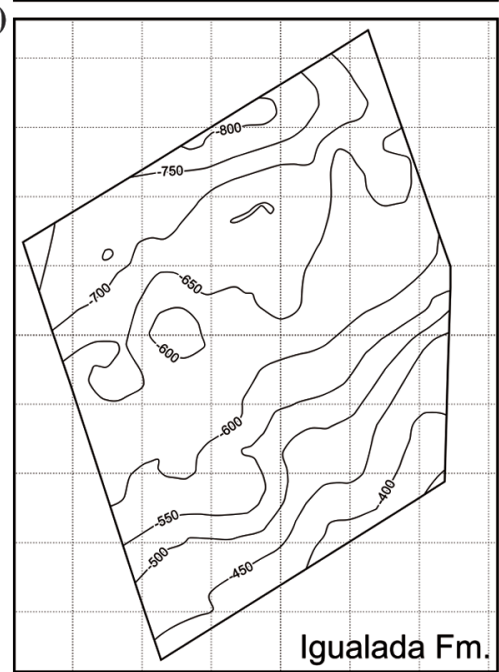

c)

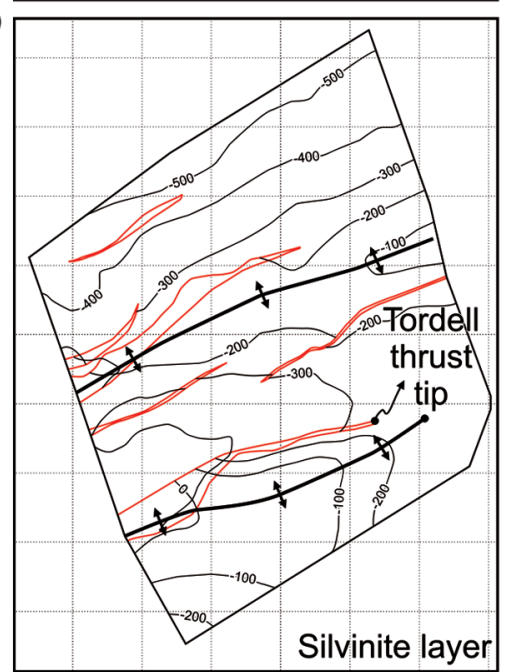

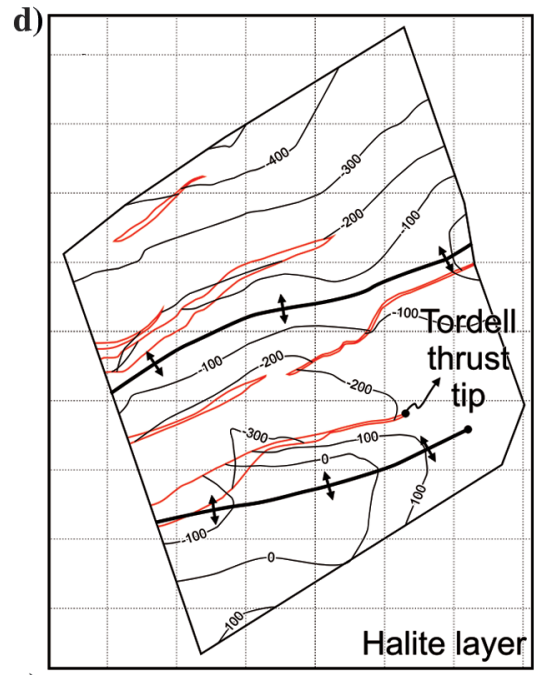

e)

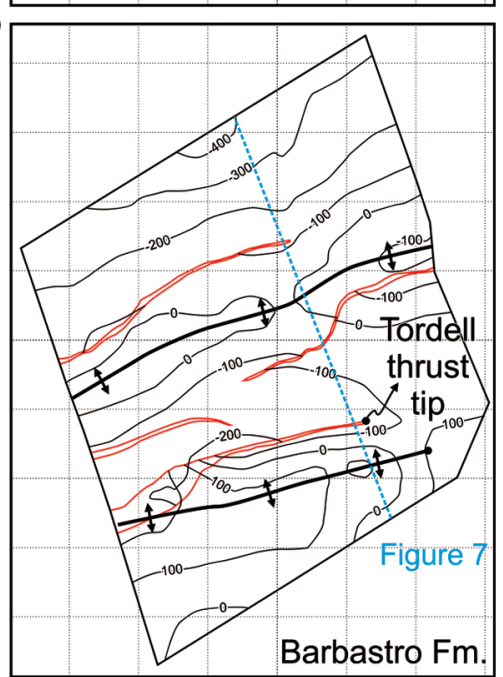

f)

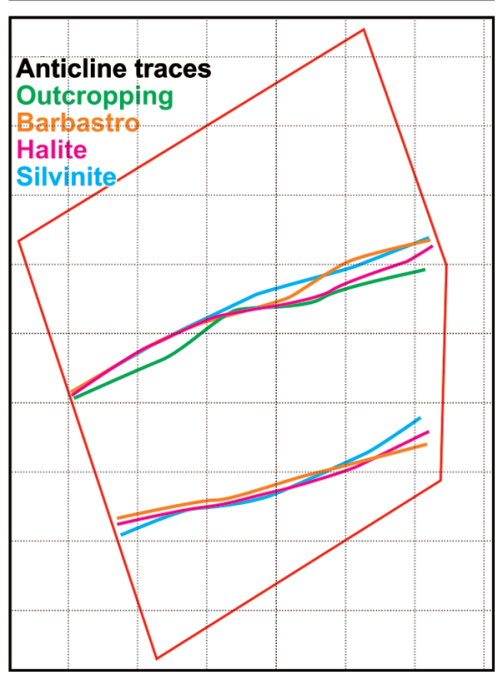

Figure 7. (a) The 3D views of the structural model showing the main structural elements and interpreted horizons. (b) Map of the Igualada Formation surface. Notice the absence of structures in this autochthonous layer (below the major detachment) and how the regional dip is toward the north. (c-e) Maps of the Top Silvinite and Halite of the Cardona Formation and Barbastro layers with the location of the main interpreted structures (faults and anticlines). (f) Location of the anticline traces interpreted from the seismic lines (Silvinite, Halite, and Barbastro) and the outcropping trace from surface data superposed. Notice how the units share the same traces except for the outcropping one that is only present in the footwall of the main fault in the area. 
Agrawal, 2002; Soto et al., 2002, 2003; Luján et al., 2003; Teixell and Koyi, 2003; Mourgues and Cobbold, 2006; Graveleau et al., 2012). In this case, all parameters were fixed, and the factor controlling the decrease in thrust spacing was the extent of the ductile layer. Mapping the deformation front through time in the analog models can provide information about where salt inflation takes place and where a new structure is generated. In addition, the location and advance rate of the deformation front cannot be taken as an indicator for the total shortening absorbed between two stages of deformation because hinterland structures could have been active thus reducing the advance of the deformation front. As demonstrated by many authors, active structures in the hinterland or reactivation of those may trigger the generation of additional structural relief, increasing the taper and facilitating the transfer of defor- mation toward the foreland (Davis et al., 1983; Dahlen, 1990). The same process is described in the analog models shown in Figure 10, in which hinterland structures were reactivated as deformation progressed and increased the structural relief of the thrust belt. Another mechanism that increases the taper angle and allows transferring the deformation toward the foreland is the overprinting of hinterland structures.

Analog modeling of frontal structures and thrust wedges has been studied by many authors covering a broad range of configurations. Some of them tested the effect of lacking an effective detachment level, different basal friction effects, or preexisting topographic relief (Storti and Salvini, 1997; Agarwal and Agrawal, 2002; Nilforoushan et al., 2008; Graveleau et al., 2012; Sun et al., 2016). In contrast, others tested the effect of thrust development conditioned by the presence of

a)

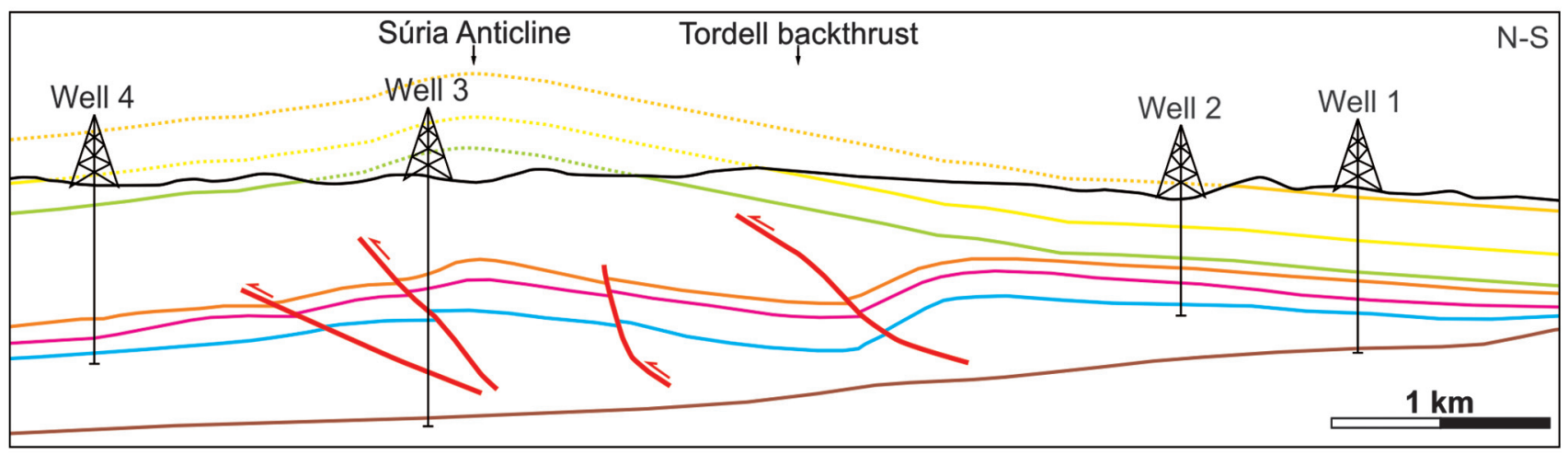

b)

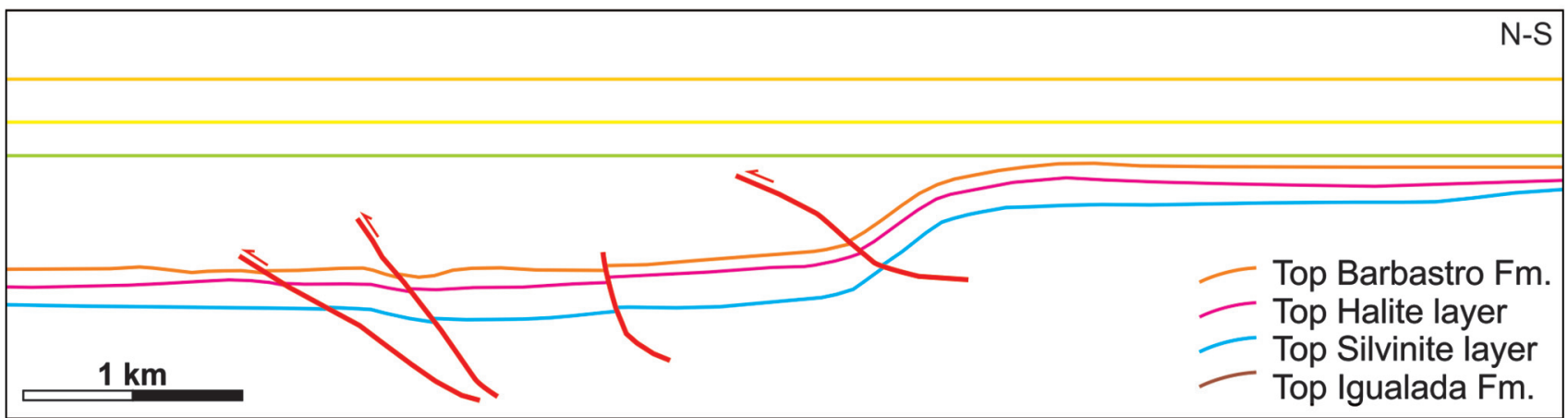

c)

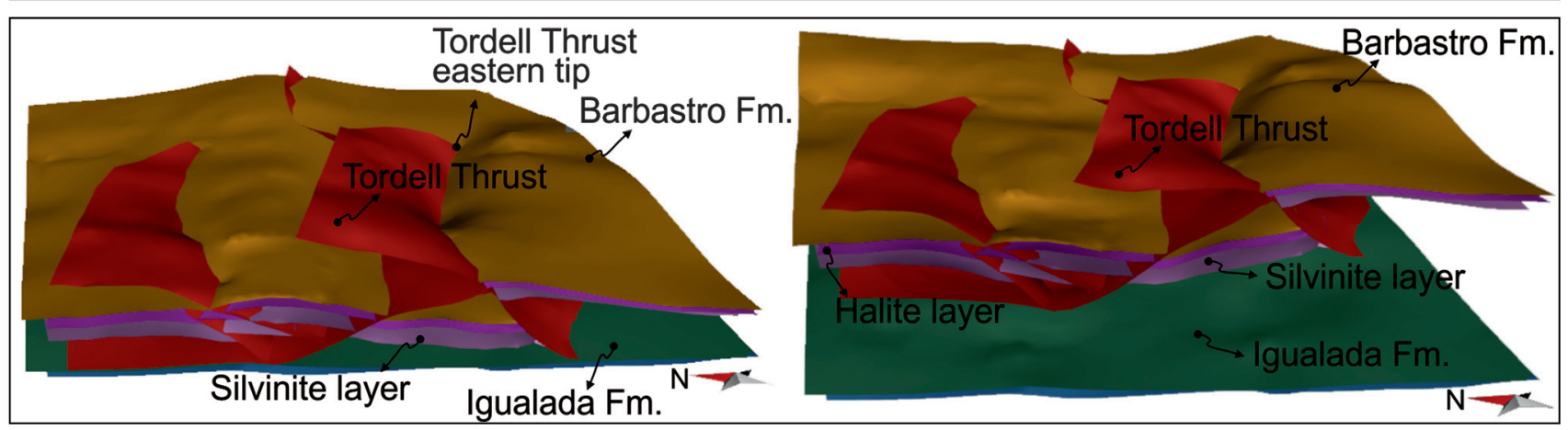

Figure 8. (a) North-south cross section constrained by seismic, well, and surface data. (b) Cross section restoring the outcropping layers to the prefolding stage to understand the geometry of the area. (c) Three-dimensional views of the actual geometry of the model showing the main units labeled and geometry of the 3D model once the outcropping surface is restored to the horizontal. Notice that the autochthonous is not restored due to the presence of salt. See the text for more details about stratigraphy and Figure 7e for the location. 
one or several detachment levels (Bahroudi and Koyi, 2003; Bonini, 2003; Luján et al., 2003; Vidal-Royo et al., 2009; Tang et al., 2010) and even the effect of gravitydriven thrust development with a basal detachment (Dooley et al., 2007). In the specific case of multiple detachments, the effect of spatial distribution of these detachments or the amount of overlap between them has been studied (Couzens-Schultz et al., 2003; Sans, 2003; Koyi and Sans, 2006; Sherkati et al., 2006; Santolaria et al., 2015). Reported models with a similar setup using two detachment levels show comparable results thus reinforcing the reproducibility that analog modeling provides. The big picture of these models shows that the deformation is easily transferred from the lower detachment to the upper one (Couzens-Schultz et al., 2003; Sherkati et al., 2006; among others). In models with two detachments covering the whole area, decoupling between the deeper and shallower levels is the typical result. In contrast, the models in which the detachment layers are restricted to a local area with a certain overlap between them (positive or negative) do not develop structural decoupling but a broad thrust at the lower foreland salt pinch-out that transfers the deformation from lower structural levels to upper levels (this study and also Sans, 2003; Koyi and Sans, 2006; Santolaria et al., 2015).

The most similar model setups with two detachments compared with the presented in this study are the ones reported by Koyi and Sans (2006) and Santolaria et al. (2015). The most important differences between them are the velocity and the thicknesses used in the models. In this study, a $3 \mathrm{~cm} / \mathrm{h}$ convergence rate and a $2.5 \mathrm{~cm}$ thick succession are used. In comparison, Santolaria et al. (2015) use a velocity of $0.5 \mathrm{~cm} / \mathrm{h}$ and a thickness $2.8 \mathrm{~cm}$, whereas Koyi and Sans (2006) use a rate of $2 \mathrm{~cm} / \mathrm{h}$ and a thickness of $4.3 \mathrm{~cm}$. The main observation is that the thrusts and backthrusts are developed with the different sets of models and that there is no clear vergence of the frontal thrusts and associated folds. Costa and Vendeville (2002) propose that a deformable backstop and a foreland pinch-out favored the preferential development of forethrusts, asymmetric folds, and tilting of the bedding toward the hinterland. However, with the examples given above, there is not a clear relationship between the two variables (i.e., deformable backstop and salt pinch-out) and the asymmetry. Costa and Vendeville (2002) also suggest that the thickness ratio between brittle and ductile layers can influence the asymmetry in thrust development. The brittle/ductile ratio for the external parts of the models (from the base of the upper detachment up to the top of the model) is 65/35 in our model and 83/ 17 in the model from Koyi and Sans (2006). Santolaria et al. (2015) do not provide this information, but by analyzing the reported results, it seems reasonable to assume a ratio between $70 / 30$ and $60 / 40$. As can be seen, the three works cover a broad range of brittle/ductile ratios. We do not observe a clear relationship between this ratio and the vergence of thrusts. In our opinion,

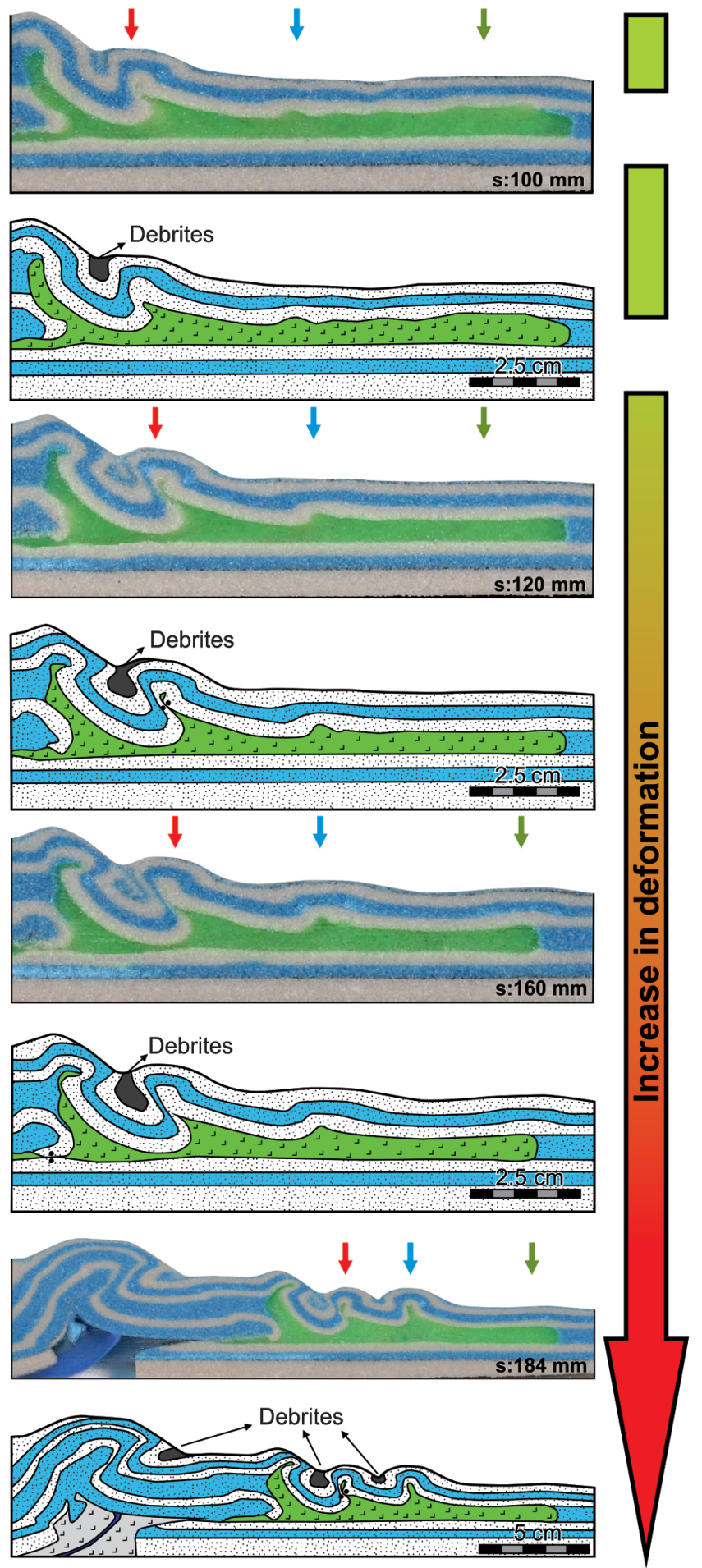

Figure 9. Selected cross sections of the model with two detachment levels showing the across-strike variation of the foreland structures as deformation increases. The green arrow marks the location of salt inflated areas. The blue arrow shows the position of a detached anticline. The red arrow is indicating the backthrust developed. Note that the lower image is in a different scale and shows the whole final deformation step of the model. Debrites correspond to the sediments that collapsed from the anticlines and thus infill the space in the synclines. 
this is a key aspect in analog modeling that should be systematically addressed in the near future.

The 3D structural modeling and restoration of the Súria Anticline and the Tordell Thrust revealed a $2 \%$ bulk shortening due to anticline development. Sans (2003) and Koyi et al. (2003) calculate that the amount of shortening associated to the formation of the Súria Anticline and the Tordell Thrust could account for $10 \%$ in a section located more to the west of the study area where the thrust exhibits more displacement. The value we propose is in line with observations by Sans (2003) and Koyi et al. (2003) given that, in our study, the effect of layer-parallel shortening, the shortening by the Tordell Thrust, and the associated anticline have not been restored and also that the study area is located at the eastern tip of the thrust. Our structural evolution is also in line with the evolution proposed by Sans et al. (1996) and Sans (2003) for the Sanaüja and El Guix Anticlines. These two anticlines are located in a more external position within the South Pyrenean Triangle Zone (Figure $1 \mathrm{~b}$ and $1 \mathrm{c}$ ). The reported evolution is characterized by an initial stage of salt inflation and a later thrust development and anticline breakthrough. These two structures can be compared with the evolution proposed for the studied area, although the Sanaüja and El Guix Anticlines are less developed structures than the Súria Anticline (i.e., no reactivation is observed for the Sanaüja and El Guix Anticlines).

The methodology used in this study can be used in other fold and thrust belts in which several detachment a)

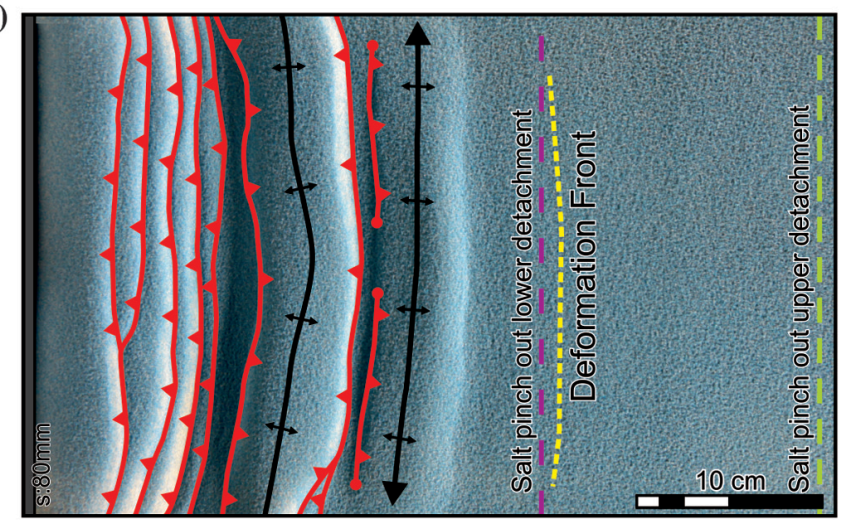

b)

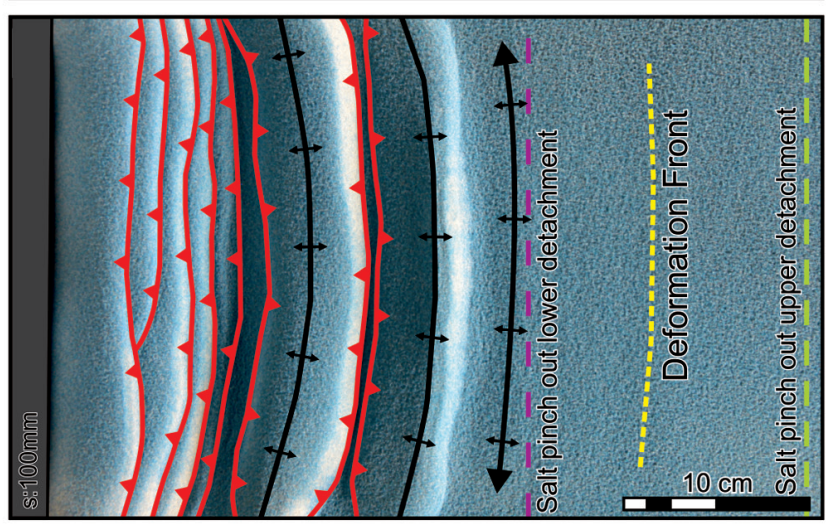

c)

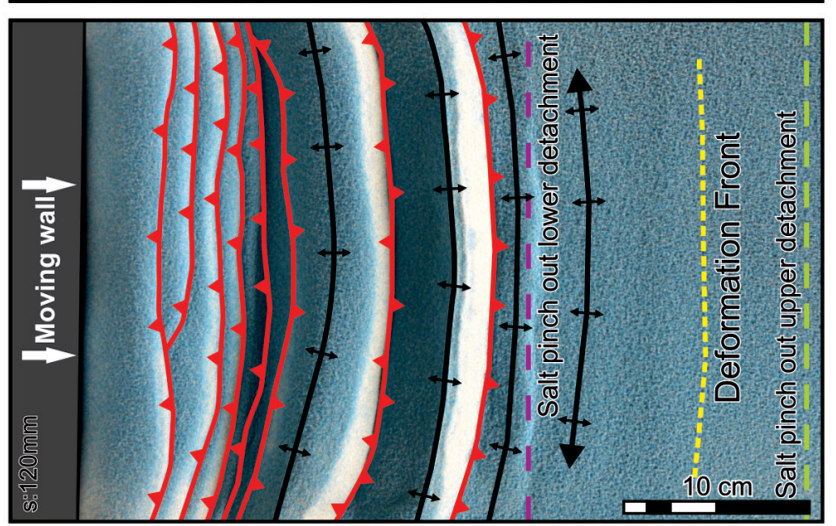

d)

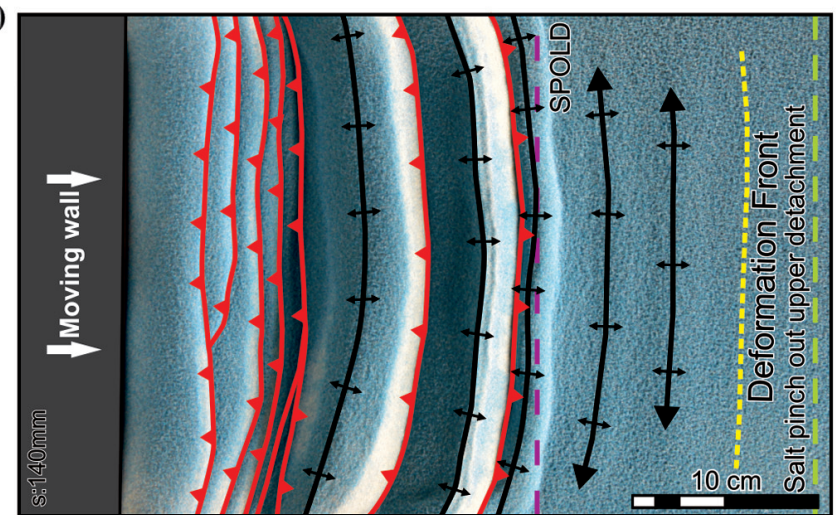

e)

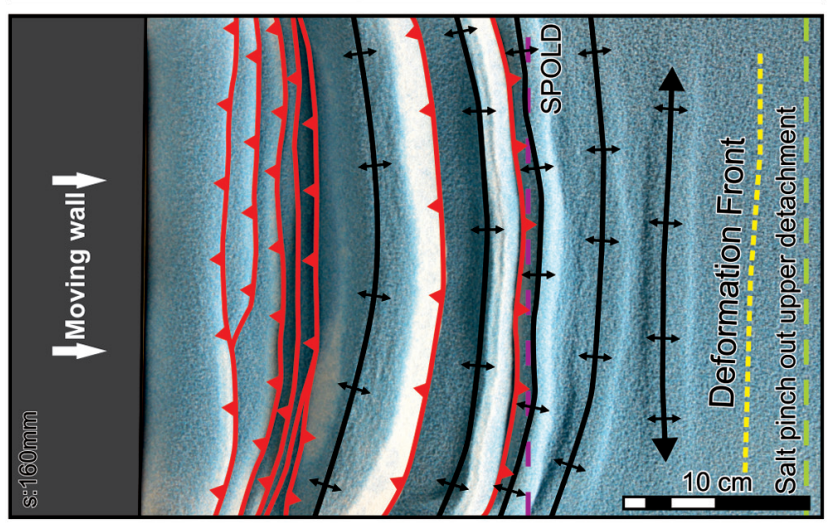

f)

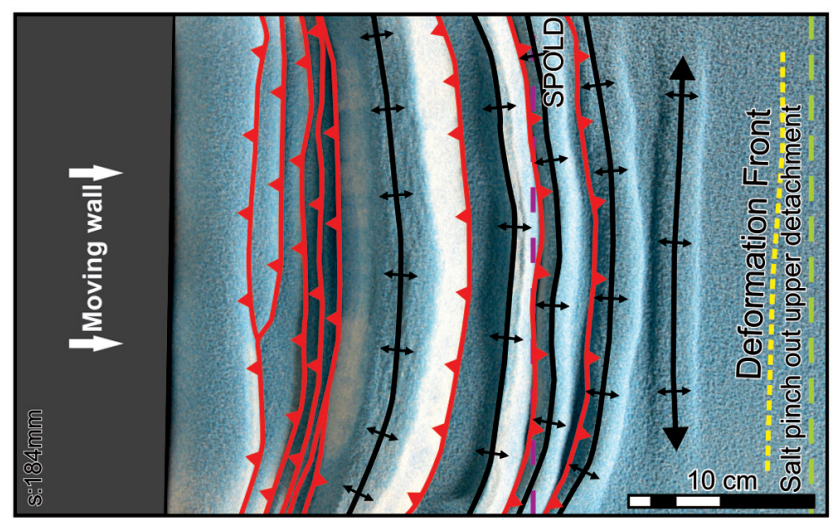

Figure 10. Top-view images in different time steps of the model with two detachment layers showing the evolution of the deformation front, the detached anticlines, and thrusts and backthrusts. SPOLD corresponds to salt pinch-out lower detachment. See the text for more details. 
levels are present, where the coverage or quality of seismic data is not good enough to constrain the evolution of structures (e.g., the Dinaride-Hellenide fold and thrust belt that overrides the Apulian-Adriatic foreland, the foreland detached folds of the southwestern Tian Shan and Tamir areas, or the simply folded belt of the Zagros, the Canadian Foothills, or the Southern Appalachians, among others). In such conditions, the integration of surface data together with analog modeling experiments constrains all possible interpretations down to a small range of solid reproducible structural evolution paths.

\section{Conclusions}

This integrated study demonstrates that the displacement along the main studied fault (the Tordell Thrust) decreases toward the eastern tip of the fault. This decrease in displacement is constrained by surface and subsurface data. The 3D geologic model coupled with observations from analog modeling allowed to characterize and to better understand the geometry and evolution of the studied area.

The evolution at early stages of deformation in the studied area and in analog modeling is characterized by salt inflation driven by shortening. With increasing shortening, a detachment anticline starts to grow together with the development of a backthrust in the studied area and thrust and backthrust in analog modeling, which accommodates most of the deformation. This process increases the structural relief and transfers the deformation toward the foreland. In the experimental models, the development of frontal structures is characterized by a cyclic process when shallower detachment layers with horizontal and vertical offset are present. Moreover, the spacing between structures decreases when reaching the salt pinch-out. Finally, the folding of the structures is produced during a later reactivation generating the Súria anticline. In contrast, cannibalization of preexisting structures occurs in analog modeling. The results of both processes are the increase of the taper angle of the orogen and the concealing of deformation at deeper structural levels.

\section{Acknowledgments}

This work was carried out under the financial support of the SALTECRES project (CGL20114-54118-C21-R MINECO/FEDER, UE) as the Grup de Recerca de Geodinamica i Analisi de Conques (2014SRG467). We would like to thank Gas Natural Fenosa to allow publication of some of the figures presented here. The GEOMODELS Analogue Modelling Laboratory was supported by a Scientific Infrastructure (UNBA08-4E-006) cofunded by the European Regional Development Fund of the Ministerio de Ciencia e Innovación of the Spanish Government and Statoil. We would like to thank T. Dooley, G. Corti, R. Soto, and M. Bonini for the fruitful and constructive review that helped to improve the initial manuscript. Finally, Schlumberger, Paradigm, and Mid- land Valley are thanked for providing academic licenses for Petrel, GoCad, and Move, respectively.

\section{References}

Agarwal, K. K., and G. K. Agrawal, 2002, Analogue sandbox models of thrust wedges with variable basal frictions: Gondwana Research, 5, 641-647, doi: 10.1016/ S1342-937X(05)70635-3.

Bahroudi, A., and H. A. Koyi, 2003, Effect of spatial distribution of Hormuz salt on deformation style in the Zagros fold and thrust belt: An analogue modelling approach: Journal of the Geological Society, 160, 719-733, doi: 10.1144/0016-764902-135.

Beaumont, C., J. A. Muñoz, J. Hamilton, and P. Fullsack, 2000, Factors controlling the Alpine Evolution of the central Pyrenees inferred from a comparison of observations and geodynamical models: Journal of Geophysical Research, 105, 8121-8145, doi: 10.1029/ 1999JB900390.

Biteau, J. J., A. Le Marrec, M. Le Vot, and J. M. Massot, 2006, The aquitanie basin: Petroleum Geoscience, 12, 247-273, doi: 10.1144/1354-079305-674.

Bonini, M., 2001, Passive roof thrusting and forelandward fold propagation in scaled brittle-ductile physical models of thrust wedges: Journal of Geophysical Research, 106, 2291-2311, doi: 10.1029/2000JB900310.

Bonini, M., 2003, Detachment folding, fold amplification, and diapirism in thrust wedge experiments: Tectonics, 22, doi: 10.1029/2002TC001458.

Busquets, P., F. Ortí, J. J. Pueyo, O. Riba, A. Sáez, R. Salas, and C. Taberner, 1985, Evaporite deposition and diagenesis in the saline (potash) Catalan basin, Upper Eocene: Excursion Guide Book 6th European Meeting, 13-59.

Carola, E., J. A. Muñoz, and E. Roca, 2015, The transition from thick-skinned to thin-skinned tectonics in the Basque-Cantabrian Pyrenees: The Burgalesa Platform and surroundings: International Journal of Earth Science, 104, 2215-2239, doi: 10.1007/s00531-015-1177-z.

Costa, E., and B. C. Vendeville, 2002, Experimental insights on the geometry and kinematics of fold-and-thrust belts above a weak, viscous evaporite décollement: Journal of Structural Geology, 24, 1729-1739, doi: 10.1016/ S0191-8141(01)00169-9.

Couzens-Schultz, B. A., B. C. Vendeville, and D. V. Wiltschko, 2003, Duplex style and triangle zone formation: Insights from physical modeling: Journal of Structural Geology, 25, 1623-1644, doi: 10.1016/S0191-8141(03)00004-X.

Dahlen, F. A., 1990, Critial taper model of fold-and-thrust belts and accretionary wedges: Annual Review Earth Planetary Science, 18, 55-99, doi: 10.1146/annurev.ea .18 .050190 .000415 .

Davis, D., J. Suppe, and F. A. Dahlen, 1983, Mechanics of fold-and-thrust belts and accretionary wedges: Journal of Geophysical Research, 88, 1153-1172, doi: 10.1029/ JB088iB02p01153. 
Dell'Ertole, D., and W. P. Schellart, 2013, The development of sheath folds in viscously stratified materials in simple shear conditions: An analogue approach: Journal of Structural Geology, 56, 129-141, doi: 10.1016/j.jsg .2013.09.002.

Dooley, T. P., M. P. A. Jackson, and M. R. Hudec, 2007, Initiation and growth of salt-based thrust belts on passive margins: Results from physical models: Basin Research, 19, 165-177, doi: 10.1111/bre.2007.19.issue-1.

Dooley, T. P., M. P. A. Jackson, and M. R. Hudec, 2009, Inflation and deflation of deeply buried salt stocks during lateral shortening: Journal of Structural Geology, 31, 582-600, doi: 10.1016/j.jsg.2009.03.013.

Ferrer, J., 1971, El Paleoceno y Eoceno del borde suroriental de la Depresión del Ebro (Cataluña): Mémoires Suisses de Paléontologie, 90, 1-70.

Ferrer, O., E. Roca, B. Benjumea, J. A. Muñoz, and N. Ellouz, and MARCONI Team, 2008, The deep seismic reflection MARCONI-3 profile: Role of extensional Mesozoic structure during the Pyrenean contractional deformation at the eastern part of the Bay of Biscay: Marine and Petroleum Geology, 25, 714-730, doi: 10 .1016/j.marpetgeo.2008.06.002.

Fillon, C., D. Pedreira, P. A. van der Beek, R. S. Huismans, L. Barbero, and L. Pulgar, 2016, Alpine exhumation of the central Cantabrian Mountains, Northwest Spain: Tectonics, 35, 339-356, doi: 10.1002/tect.v35.2.

Gallastegui, J., 2000, Estructura cortical de la Cordillera y Margen Continental Cantábricos: Perfiles ESCI-N. Trabajos Geología, 22, 9-234.

Graveleau, F., J. Malavielle, and S. Dominguez, 2012, Experimental modelling of orogenic wedges: A review: Tectonophysics, 538-540, 1-66, doi: 10.1016/j.tecto .2012.01.027.

ICC, 2006, Mapa geològic comarcal de Catalunya 1:50.000. Bages, Base geológica de Catalunya: Síntesi geológica a partir del "Mapa Geológico de España 1:50.000, Serie MAGNA."

Jackson, M. P. A., and M. R. Hudec, 2005, Stratigraphic record of translation down ramps in a passive-margin salt detachment: Journal of Structural Geology, 27, 889911, doi: 10.1016/j.jsg.2005.01.010.

Koyi, H. A., and M. Sans, 2006, Deformation transfer in viscous detachments: Comparison of sandbox models to the south Pyrenean Triangle Zone, in S. J. H. Buiter, and G. Screurs, eds., Analogue and numerical modeling of crustal-scale processes: Geological Society of London, Special Publications 253, 117-134.

Koyi, H. A., M. Sans, A. Teixell, J. Cotton, and H. Zeyen, 2003, The significance of penetrative strain in the restoration of shortened layers - Insights from sand models and the Spanish Pyrenees, in K. R. McClay, ed., Thrust tectonics and hydrocarbon systems: AAPG Memoir 82, 1-16.

Le Pichon, X., and J. C. Sibuet, 1971, Western extension of boundary between European and Iberian plates during the Pyrenean orogeny: Earth and Planetary Science Letters, 12, 83-88, doi: 10.1016/0012-821X(71)90058-6.

Letouzey, J., B. Colletta, R. Vially, and J. C. Chermette, 1995, Evolution of salt-related structures in compressional settings, in M. P. A. Jackson, D. G. Roberts, and S. Snelson, eds., Salt tectonics - A global perspective: AAPG Memoir 65, 41-60.

Luján, M., F. Storti, J. C. Balanyá, A. Crespo-Blanc, and F. Rossetti, 2003, Role of décollement material with different rheological properties in the structure of the Alkibe thrust imbricate (Flysch Treough, Gibraltar Arc): An analogue modelling approach: Journal of Structural Geology, 25, 867-881, doi: 10.1016/S0191-8141(02)00087-1.

Martín-González, F., and N. Heredia, 2011, Complex tectonic and tectonostratigraphic evolution of an Alpine foreland basin: The western Duero Basin and the related Tertiary depressions of the NW Iberian Peninsula: Tectonophysics, 502, 75-89, doi: 10.1016/j.tecto.2010.03 .002 .

Martínez, P. B., J. Vergés, E. Clavell, and J. Kennedy, 1989, Stratigraphic framework of the thrust geometry and structural inversion in the southeastern Pyrenees: La Garrotxa area: Geodinamica Acta, 3, 185-194, doi: 10 .1080/09853111.1989.11105185.

Martínez-Torres, L. M., 1993, Corte balanceado de la Sierra Cantabria (cabalgamiento de la Cuenca Vasco-Cantábrica sobre la Cuenca del Ebro): Geogaceta, 14, 113-115.

Mencos, J., N. Carrera, and J. A. Muñoz, 2015, Influence of rift basin geometry on the subsequent postrift sedimentation and basin inversion: The Organyà Basin and the Bóixols thrust sheet (south central Pyrenees): Tectonics, 34, 1452-1474, doi: 10.1002/tect.v34.7.

Mourgues, R., and P. R. Cobbold, 2006, Thrust wedges and fluid overpressures: Sandbox models involving pore fluids: Journal of Geophysical Research, 111, doi: 10.1029/ 2004JB003441.

Muñoz, J. A., 1992, Evolution of a continental collision belt: ECORS-Pyrenees crustal balanced section, in K. R. Sesu, ed., Thrust tectonics: Chapman and Hall, 235-246.

Muñoz, J. A., 2002, The Pyrenees, in W. Gibbons, and T. Moreno, eds., The geology of Spain: Geological Society of London, 370-385.

Muñoz, J. A., E. Beamud, O. Fernández, P. Arbués, J. Dinarès-Turell, and J. Poblet, 2013, The Ainsa fold and thrust oblique zone of the central Pyrenees: Kinematics of a curved contractional system from paleomagnetic and structural data: Tectonics, 32, doi: 10.1002/tect .20070 .

Nilforoushan, F., H. A. Koyi, J. O. H. Swantesson, and C. J. Talbot, 2008, Effect of basal friction on surface and volumetric strain in models of convergent settings measured by laser scanner: Journal of Structural Geology, 30, 366-379, doi: 10.1016/j.jsg.2007.09.013.

Pedreira, D., J. A. Pulgar, J. Gallart, and J. Díaz, 2003, Seis- 5 mic evidence of Alpine crustal thickening and wedging from the western Pyrenees to the Cantabrian Mountains 
(north Iberia): Journal of Geophysical Research, 108, 2208, doi: 10.1029/2001JB001667.

Pueyo, J. J., 1975, Estudio petrológico y geoquímico de los yacimientos potásicos de Cardona, Súria, Sallent (Barcelona, España): Doctoral thesis, Universitat de Barcelona.

Puigdefàbregas, C., J. A. Muñoz, and M. Marzo, 1986, Thrust belt development in the Eastern Pyrenees and related depositional sequences in the southern foreland basin, in P. A. Allen, and P. Homewood, eds., Foreland Basins: Special Publication of the International Association of Sedimentologists 8, 229-246.

Pulgar, J. A., J. Gallart, G. Fernández-Viejo, A. PérezEstaún, and J. Álvarez-Marrón, 1996, Seismic image of the Cantabrian Mountains in the western extension of the Pyrenees from integrated ESCIN reflection and refraction data: Tectonophysics, 264, 1-19, doi: 10.1016/ S0040-1951(96)00114-X.

Ramírez del Pozo, J., O. Riba, and O. Maldonado, 1973, Mapa geológico de España 1:50.000. Hoja 331, Puigreig: Instituto Geológico y Minero de España, 52.

Reguant, S., 1967, El Eoceno marin de Vic (Barcelona): Memorias Instituyto Geológico y Minero de España, 68, $1-350$

Rosell, L., and J. J. Pueyo, 1997, Second marine evaporitic phase in the South Pyrenean foredeep: The priabonian potash basin, in G. Busson, and B. C. Schreiber, eds., Sedimentary deposition in rift and foreland basins in France and Spain (Paleogene and Lower Neogene): Columbia University Press, 358-387.

Sáez, A., 1987, Estratigrafía y sedimentología de las formaciones lacustres del tránsito Eoceno Oligoceno del NE de la cuenca del Ebro: Doctoral Thesis, Universitat de Barcelona.

Santolaria, P., B. C. Vendeville, F. Graveleau, R. Soto, and A. Casas-Sainz, 2015, Double evaporitic décollements: Influence of pinch-out overlapping in experimental thrust wedges: Journal of Structural Geology, 76, 35-51, doi: 10.1016/j.jsg.2015.04.002.

Sans, M., 2003, From thrust tectonics to diapirism. The role of evaporates in the kinematic evolution of the eastern South Pyrenean front: Geologica Acta, 3, 239-259.

Sans, M., J. A. Muñoz, and J. Vergés, 1996, Triangle zone and thrust wedge geometries related to evaporitic horizons (southern Pyrenees): Bulletin of Canadian Petroleum Geology, 44, 375-384.

Sans, M., and J. Vergés, 1995, Fold development related to contractional salt tectonics: Southeastern Pyrenean Trust Front, Spain, in M. P. A. Jackson, D. G. Roberts, and S. Snelson, eds., Salt tectonics: A global perspective: AAPG Memoir 65, 369-378.

Sans, M., J. Vergés, E. Gomis, J. M. Parés, M. Schiattarella, A. Travé, F. Calvet, P. Santanach, and A. Doulcet, 2003, Layer parallel shortening in salt-detached folds: Constraint on cross-section restoration: Tectonophysics, 372, 85-104, doi: 10.1016/S0040-1951(03)00233-6.
Schellart, W. P., 2000, Shear test results for cohesion and friction coefficients for different granular materials: Scaling implications for their usage in analogue modeling: Tectonophysics, 324, 1-16, doi: 10.1016/S0040-1951 (00)00111-6.

Sherkati, S., J. Letouzey, and D. Frzon de Lamotte, 2006, Central Zagros fold-thrust belt (Iran): New insights from seismic data, field observation, and sandbox modeling: Tectonics, 25, TC4007, doi: 10.1029/2004TC001766.

Soto, R., A. M. Casas, F. Storti, and C. Faccenna, 2002, Role of lateral thickness variation on the development of oblique structures at the Western end of the South Pyrenean Central Unit: Tectonophysics, 350, 215-235, doi: 10.1016/S0040-1951(02)00116-6.

Soto, R., A. M. Casas, F. Storti, and C. Faccenna, 2003, Influence of along-strike pre-orogenic sedimentary tapering on the internal architecture of experimental thrust wedges: Geological Magazine, 140, 253-264, doi: 10 .1017/S0016756803007817.

Storti, F., and F. Salvini, 1997, Fault-related folding in sandbox analogue models of thrust wedges: Journal of Structural Geology, 19, 583-602, doi: 10.1016/S0191-8141(97) 83029-5.

Sun, C., D. Jia, H. Yin, Z. Chen, Z. Li, L. Shen, D. Wei, Y. Li, B. Yan, M. Wang, S. Fang, and J. Cui, 2016, Sandbox modeling of evolving thrust wedges with different preexisting topographic relief: Implications for the Longmen Shan thrust belt, eastern Tibet: Journal of Geophysical Research Solid Earth, 121, 4591-4614, doi: 10.1002/2016JB013013.

Tang, P., B. C. Vendeville, S. Huang, and Y. Guillot, 2010, Influence of salt-related, thinskinned deformation on basement thrust evolution: Physical modeling applied to the Kuqa Basin (Southern Tian-Shan): GeoMod.

Tavani, S., P. Arbués, M. Snidero, N. Carrera, and J. A. Muñoz, 2011, Open Plot Project: An open-source toolkit for 3-D structural data analysis: Solid Earth, 2, 53-63, doi: 10.5194/se-2-53-2011.

Teixell, A., and H. A. Koyi, 2003, Experimental and field study of the effect of lithological contrasts on thrust-related deformation: Tectonics, 22, 1054, doi: 10.1029/ 2002 TC001407.

Vergés, J., M. Fernàndez, and A. Martínez, 2002, The Pyrenean orogen: Pre-, syn-, and post-collisional evolution: Journal of the Virtual Explorer, 8, 55-74.

Vergés, J., and J. A. Muñoz, 1990, Thrust sequences in the southern Central Pyrenees: Bulletin de la Société géologique de France, VI, 265-271, doi: 10.2113/gssgfbull. VI.2.265.

Vergés, J., J. A. Muñoz, and A. Martínez, 1992, South Pyrenean fold and thrust belt: The role of foreland evaporitic levels in thrust geometry, in K. McClay, ed., Thrust tectonics: Chapman and Hall, 255-264.

Vidal-Royo, O., H. A. Koyi, and J. A. Muñoz, 2009, Formation of orogeny-perpendicular thrusts due to mechanical contrasts in the basal décollement in the Central 
External Sierras (Southern Pyrenees, Spain): Journal of Structural Geology, 31, 523-539, doi: 10.1016/j.jsg.2009 .03 .011 .

Weijermars, R., M. P. A. Jackson, and B. C. Vendeville, 1993, Rheological and tectonic modeling of salt provinces: Tectonophysics, 217, 143-174, doi: 10.1016/ 0040-1951(93)90208-2.

Zapata, T. R., and R. W. Allmendinger, 1996, Growth stratal records of instantaneous and progressive limb rotation in the Precordillera thrust belt and Bermejo basin, Argentina: Tectonics, 15, 1065-1083, doi: 10.1029/ $96 \mathrm{TC} 00431$.

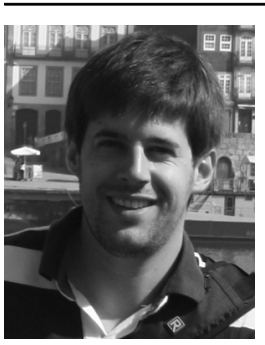

Eloi Carola received a B.S. (2009) in geology, an M.S. (2010) in sedimentary reservoirs, and a Ph.D. (2014) in earth science from the University of Barcelona. After doing some consultancy and training, he joined Gas Natural Fenosa as a structural and exploration geologist. His research interests include evolution and tectono-sedimentary relationships of salt tectonics, fold and thrust belts, and associated foreland basins.

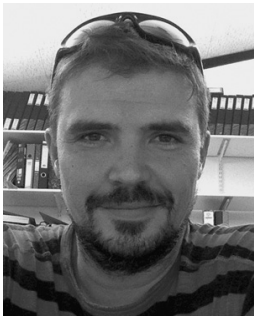

Oriol Ferrer received a B.S. and a Ph.D. in earth sciences from the University of Barcelona (UB). Then, he did a postdoc at the Fault Dynamics Research Group (Royal Holloway University of London). Since 2010, he has been in charge of the GEOMODELS Analogue Modelling Laboratory, UB. He is a tenured lecturer at UB. His research interests include salt tectonics of rift systems, inverted basins, and salt-bearing passive margins using outcrop, subsurface, and analog modeling.

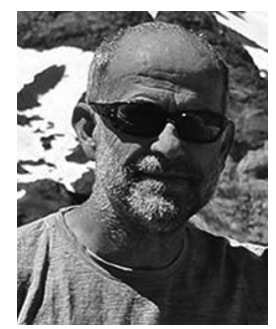

Josep Anton Muñoz received a Ph.D. (1985) from the Universitat de Barcelona (UB) and worked for the Servei Geologic de Catalunya from 1985 to 1990 , when he joined UB, where he is a professor of structural geology. He also is the director of the GEOMODELS Research Institute. His research interests include the structure of thrust and fold belts, tectonosedimentary relationships, tectonics of collisional orogens, and construction of $3 \mathrm{D}$ structural models. 


\section{Queries}

1. Please check the term " $\mu \mathrm{m}$ " in the sentence "Well-sorted dry sand of $199 \mu \mathrm{m}$ was used..." is correct.

2. Please provide the page range for Bonini (2003).

3. Please provide the page range for Mourgues and Cobbold (2006).

4. Please provide the page range for Muñoz et al. (2013).

5. Please provide the page range for Pedreira et al. (2003).

6. Please provide more publication details for the reference "Tang et al. (2010)."

7. Is it correct that author Vidal-Royo does not wish to add an optional biography and photograph to this paper? 